\title{
'Something is Trying to Get Inside My Body': A Gay Reception and Narrative Analysis of $A$ Nightmare on Elm Street 2: Freddy's Revenge
}

\author{
ADAM SCALES, University of East Anglia
}

\begin{abstract}
The critical understanding of horror film has traditionally been locked into a particular psychoanalytic framework concerning audience composition of the genre, as well as the identity politics operating within (Twitchell 1985; Carroll 1990; Clover 1992; Creed 1993; Grant 1996). Within this work, little attention has been paid to alternative audience demographics, especially gay and sexually non-normative viewers. This is rather surprising considering the horror film, and the monster in particular, has been understood as a material manifestation of queerness, as that which bourgeois ideology cannot accept and must therefore construct as 'Other' (Benshoff 1997; Wood 1986; Saunders 1998). As a result, this article looks at a gay online reception of gay audiences of $A$ Nightmare on Elm Street 2: Freddy's Revenge (Jack Sholder, 1985). Such a text is important, as it fractures the established formula of the slasher film by introducing a 'male scream queen' - a 'final boy' named Jesse Walsh (Mark Patton). This article employs Janet Staiger's (2000) work on reception studies to argue that the strategies and tactics brought by the spectator to the filmic experience are constructed by particular historical circumstances, which in turn, assist in the formation of 'interpretive communities'. While the introduction of the final boy certainly disrupts fixed points of gendered identification, such features are only part of a holistic approach to understanding the subjective responses of gay audiences to Jesse's characterisation. Textual subversions therefore mobilise gay audiences' affective responses to the film - as Jesse's narrative struggles mirror the lived experiences of gay audiences as they relate to the social context of homosexuality in the $1980 \mathrm{~s}$.
\end{abstract}

\section{KEYWORDS}

Reception, audiences, online, slasher, horror, homosexuality.

\section{Introduction}

A Nightmare on Elm Street 2: Freddy's Revenge (Jack Sholder) is a 1985 slasher sequel to Wes Craven's successful film from the previous year A Nightmare on Elm Street. Since the film's release, gay audiences have focalised the text in a series of ways in a number of online spaces. Within these spaces, the film has been scrutinised for its ostensibly gay narrative, a driving force that has constituted much of the film's online reception. It might be seen as striking that this instalment in a notable mainstream slasher franchise from the $1980 \mathrm{~s}$ is being understood, in a number of ways, as a text that speaks about a series of homosexual processes and, in a fundamental way, of being gay in the 1980s. Despite the fact that the film's protagonist Jesse Walsh (Mark 
Patton) is never revealed as being homosexual, much of the film's reception engineers Jesse's journey as one in which he seeks to handle a series of homosexual urges that are surfaced via parallels drawn between his own (gay) identity and those tenanted by self-identified gay audiences who discursively interrogate the film. Although a cursory glance at the film's online reception could suggest that the film registers as homophobic, even retrograde, there is a sense in which the film is received as actually being politically progressive for its subtle, yet discernable depictions of homosexuality, especially when considered in the conservative slasher context of the 1980s.

Employing Janet Staiger's work on reception studies, this article argues that the strategies and tactics brought by the spectator to the filmic experience 'are historically constructed by particular historical circumstances. The historical circumstances sometimes create "interpretive communities" or cultural groups who produce their own conventionalized modes of reception' $(2000,23)$. These 'interpretive communities', I argue, seek to interrogate the narrative of the film, cultivating their own meanings as they resonate with their homosexual lived realities. However, the fact that contemporary audiences are reverting back to a film from the 1980s illuminates both the importance of gay audiences 'outing' what they believe to be a closeted film (one that they perceive as unequivocally gay), and also allowing them agency to locate a sense of their own histories and struggles discernible within the film's narrative.

In this way, the film's textual ambiguities, the consignation of homosexuality to the realm of connotation and suggestion is deciphered by gay audiences as speaking about their own sexual identities. It is important here to distinguish between A Nightmare on Elm Street 2: Freddy's Revenge (hereafter ANOES2) as an overtly gay horror film, against what Alexander Doty sees as something which is practiced by 'historically specific cultural readings and uses of texts by selfidentified gays, lesbians, bisexuals and queers' - where a wider range of reading positions are exercised (1993, xi). (Homo)sexuality is thus framed here less as incontrovertibly in the text itself and more as something produced and negotiated at multiple sites of reception by self-identified gay audiences.

This article is primarily concerned with the ways in which male gay audiences have received the text, despite the fact that the film's homosexual narrative has been received similarly within other (straight) online demographics. ${ }^{1}$ While the concern is with the ways in which gay male audiences are 'outing' an otherwise 'normative' horror film, it should be noted that the task of qualifying ANOES 2 is secondary to how gay readings of, and responses to, the film are perceived in relation to gay audiences' own (homo)sexualities as they parallel Jesse's narrative struggles. Such uses of gay, queer and non-normative readings therefore serve to respect and reflect the heterogeneity and elasticity of responses that may fall beyond the strict deployment of 'gay audience' used throughout. While audiences self-identify in their reception materials, I am nevertheless mindful of essentialising gay responses, taking into account the fluidity of experiences that may fall under the labels of homosexual or gay.

\footnotetext{
${ }^{1}$ There are a number of online spaces in which A Nightmare on Elm Street 2: Freddy's Revenge has been understood as a gay narrative. Such readings are also to be found within so-called 'normative' online blogs, forums and chat rooms. While there is little space in this article to explicate on the differences between heterosexual/male gay/lesbian/queer readings of the film, terms such as 'coding', 'subtext' and 'homoerotic' have been employed in an attempt to capture a seemingly homosexual narrative which is often read at a connotative level.
} 
Firstly, I will explain the significance of the appearance of a 'final boy' in ANOES2 to the nonnormative reception of the film, before considering examples from said reception. The second section of this article stitches together a gay reception of the film with specific narrative moments that appear to be important to gay discussions. Finally, section three proceeds to look at the cultural significance of online interpretive communities and their relationship to Mark Patton's online presence. While there are a number of online spaces that could be foregrounded through this analysis, the focus here is primarily on blogs (such as those on Blogspot.com), which are privileged as a 'gay space' - either through the author's self-identification as sexually 'non-normative', or those which foster gay readings - through a preoccupation with the links between homosexuality and popular culture. ${ }^{2}$ The reception material will be considered alongside a narrative analysis of the film which supplements, rather than supports, the reception material.

\section{'Jesse! Fight Him!': The Final Boy}

Unconventionally for the slasher sub-genre of horror in the 1980s, Jesse is configured as a 'stand in' for the traditional final girl figure who is, in Carol Clover's words, 'the one who encounters the mutilated bodies of her friends and perceives the full extent of the preceding horror and of her own peril' (1992, 35). The final girl, a staple of the slasher sub-genre, is often recognised as one of the most defining features of the slasher film, typically featuring her locked in a physical and mental showdown with the film's belligerent killer figure. Slasher precursors to ANOES2 typically reserved this figure for the morally shrewd and judicious character, existing in a pool of male and female victims defined by their social insurgence in pursuit of drugs, alcoholism and sexual promiscuity (Oliver and Sanders 2004). With a few slasher exceptions such as The Burning (Tony Maylam, 1981), that depicts the acumen of Alfred (Brian Backer) and Todd (Brian Matthews) in a precarious final encounter with burnt caretaker 'Cropsy', this figure was predominately reserved for a female character; albeit, much scholarship has focused on her liminal position between the socially inscribed roles of masculinity and femininity (Clover 1992; Berenstein 1996; Duda 2008).

It is therefore with the intersection between the ANOES2's atypical inclusion of a final boy figure and gay audiences' affective responses to the text that this article is concerned. Although Carol Clover's work accounts for the fluidity of gender and sexuality for both the slasher killer and the final girl, her analysis concerns the relationship between the latter figure and the slasher film's purportedly heterosexual, male adolescent audience. Rather than assuming, as Clover does, that the spectator shifts identification from an initial one with the killer to one with the final girl (exemplified through camera point of view), the rare inclusion of the final boy figure, I argue, allows for a more fluid account of the ways in which gay and other sexually non-normative audiences are implicated in the relationship between the killer and final boy. The displacement of this figure with a final boy, therefore, destabilises strict heterosexist spectator-character identificatory practices, allowing for wider non-normative positions to be accounted for outside of a psychoanalytic model of spectatorship. In this light, assumed heterosexist viewing positions are brought into question and gender and sexuality become spaces of struggle and negotiation.

\footnotetext{
${ }^{2}$ See Halberstam (2005) for an insightful analysis of gay temporal relations to alternative time and space which function in opposition to institutions of heteronormativity: the family, reproduction and heterosexuality.
} 
While Clover concedes that there is a degree of fluidity in slasher spectatorship - the male audience identifying with both male and female characters, Klaus Rieser (2001) argues that the slasher film actually upholds cinema's patriarchal signification by equating female(ness) with victimhood, and consequently reinstating the strict gender roles that Clover and others have challenged. While Rieser's conflation of femaleness with victimhood may have some resonance in the fundamental operations of the slasher film, his argument cannot be so easily translated to account for the existence of the final boy. In other words, the fundamental roles of victim and killer/monster, I argue, are still at play in $A N O E S 2$, however they come to be infused in the figure of the final boy as borders collapse and roles are renegotiated. As I will demonstrate, for gay audiences, the figure of the final boy compounds the victim and monster figure, as they coalesce in representing the contours of their sexual identity - at once victim to the patriarchal society in which they operate, whilst acknowledging the monster within who could erupt at any moment with its aberrant sexual identity.

\section{Elm Street: A Nightmare for the Gays}

ANOES2 follows Jesse, the high-school protagonist, whose middle-class family move into a house on Elm Street previously inhabited by Nancy Thompson played by Heather Langenkamp in the preceding film. Nancy was plagued with a series of nightmares concerning the monstrous, yet infamous figure of Freddy Krueger. Freddy, who was previously burnt alive by the residents of the street for child molestation, has regenerated himself once again. This time however, he seeks to penetrate Jesse's dreams. In this film, Freddy uses Jesse as a host body as a means to kill those close to him, but also to surface Jesse's 'repressed' desires. These desires can thus be understood as Jesse's latent homosexual ones, which are purportedly manifested through his dreams - in the monstrous form of Freddy Krueger.

Writing on the queer review website Campblood.org, the author 'Buzz' notes in a review titled 'The Gaypex of Horror Cinema' that, 'In this film we get the beginnings of a very strange journey into sexual repression, angst, and ultimately a nervous breakdown' (2009). This 'journey' that Jesse embarks upon is marked in the film through a series of stages where Jesse's homosexual identity shifts from clues or speculations in the beginning, to Jesse dreaming himself in a gay sadomasochist nightclub about halfway through the film. In this dream, Jesse meets his high school gym coach, Coach Schneider (Marshall Bell), who is coded as the film's more conspicuously gay character (through his desire for Jesse and his high school friend Grady (Robert Rusler)). This can be seen to lend itself to perceptions of a homosexual trajectory, shifting from a state of concealment to one of 'coming out' (that is to say, Jesse unveiling his fantasies through access to his perverse unconscious desires). Accordingly, Buzz goes on to note:

I'd seen this film as a child, after all! I remember the pool party scene! I remember the school bus teetering on the pile of rocks! I remember the hot guy in the nylon shorts getting pinned up against the door... hey... wait a minute... I'm getting a strange tingly feeling. (Buzz, 2009)

While candidly associating the film with 'childhood' viewing practices, Buzz acutely amalgamates the nightmarish scene with the bus 'teetering' on the rocks, with an admiration for 'the hot guy in nylon shorts'. This combines notions of horror with confirmation of a subjective desire for other men, permitting him to recollect his desire for 'guys' in the film through reference to Jesse's own nightmarish visions. It is through this pairing of Jesse's nightmares and an acknowledgment of one's own sexual deviation that the homosexual 
narrative of the film can be best understood. For one's own preternatural sexuality can be neatly located through Jesse's recurring nightmares throughout the diegesis - a space where gay fantasies can unfold in a series of imaginative, if perverse ways. Whereas in A Nightmare on Elm Street, Tina (Amanda Wyss) and Nancy reminisce over their shared dreams of Freddy Krueger (the queer penetrating the vulnerable heteronormative realm), in the sequel, Jesse is forced to traverse these foreboding realms alone where it seems nobody quite understands what he faces until close to the end of the film. As Freddy states: 'he can't fight me, I'm him'.

To a large extent then, Jesse's nightmares serve as a space where gay audiences of the film are able to relocate and indeed re-evaluate a sense of their own (formerly?) repressed (homo)sexualities. Outside these nightmares however, Jessie is forced to undergo performances of normativity. For within the narrative, Lisa (Kim Myers), Jesse's high school 'friend' subtly professes her sexual attraction to Jesse. Jesse overlooks these sexual proclamations, creating a perpetual and indeed palpable tension in the film. In his online blog Faggotyasshorror.com, self-identified gay author 'Jeffreygmm' (2009) employs ANOES2 as a case study to forge more nuanced connections between homosexuality and the horror film. He writes:

I love this movie a lot. I relate to Jesse, having had a pretty girlfriend in high school that I refused to have sex with [...]. In defence of Lisa, it's hard to be the thankless girlfriend to a gay boy in high school. They won't touch your vagina and they barely kiss you. (Jeffreygmm 2009)

Reference is made here to the idea that the film has presented the potential for a heterosexual coupling between Jesse and Lisa, only to forestall such with Jesse's internal conflicts where homosexual possibilities are brought into focus. However, the fact that this potential heterosexual coupling presents itself as realisable throughout the diegesis allows Jesse the ascendancy over his sexuality (and Lisa), authenticating his character for audiences who, like Jeffreygmm, have consciously rejected heterosexual female advances. Jesse's sexual identity is not therefore demarcated from the ideal heteronormative arena, but rather actively transcends its offerings while never actually being offered a humanly manifestation of its own. Jeffreygmm's further inference that 'Jesse continues repressing the homo within as only a teenage gay can' configures Jesse's sexuality as repressed within a particular period - those 'teenage' years when many homosexual boys are actively coming to terms with being homosexual, negotiating their sexual trajectory and surveying the ideological ramifications that such a disclosure will have on their social standing (Jeffreygmm 2009).

Jeffreygmm further states the following:

A Nightmare on Elm Street 2: Freddy's Revenge exemplifies that a slasher film is primarily about penetration and the fear of penetration. When a man is the protagonist in a slasher movie, the final girl - so to speak, it is a gay movie. Men being penetrated is gay. But I digress. (Jeffreygmm 2009)

While Carol Clover (1992) attributes penetration as an act committed by the killer towards the final girl (and, harmoniously, from male spectator to female victim through what she labels as an 'assaultive gaze'), the antithesis is presented here in which Jesse's body is penetrated by Freddy, reaffirmed in the film through Jesse's infamous line, 'Something is trying to get inside my body'. What is particularly significant here is the inference that Jesse is actually a (homosexual) stand-in 
for the slasher film's traditional inclusion of a final girl figure. Where the slasher film's final girl has to undergo a tenacious endeavor to overcome her aggressor to physically liberate herself, Jesse, understood here as the figure of the final boy, has to literally build the courage to mentally vanquish these nightmares - to physically defeat Freddy Krueger who manifests himself as a personification of Jesse's latent homosexuality. Resisting these nightmares is therefore Jesse's central quest, as a way to try and sustain his heterosexual image, while suppressing his deviant homosexual urges that are endlessly negotiated throughout the diegesis. ${ }^{3}$

Understood in this way, there is an interesting parallel to be explored between the final girl's narrative trajectory and that of Jesse. Writer and queer anthologist Vince Liaguno has explicated on the queer potential of the slasher film through his blog, 'The Queer Appeal of Slasher Films', in which he writes the following:

There is $[\ldots]$ an interesting metaphorical comparison that can be drawn between the transformation of the slasher film's 'final girl' and the coming out process. In the beginning of the slasher film, the heroine usually presents as weak, timid, uncertain of how to navigate through the situation she finds herself in; for gays, this uncertainty is the same in the coming out process. As the film progresses, the heroine transforms [...] she toughens and becomes confident in her abilities to overcome the malevolence stalking her. (Liaguno 2008)

Liaguno's analysis here implies that an application of homosexuality to the slasher film is less concerned with the final boy/girl figure than about the transition from a state of femininity (weakness, passivity) to one of masculinity (tough, active). If the final girl is often conceptualised as exhibiting both genders - shifting from a state of femininity to masculinity as the narrative unfolds, Jesse oscillates between both poles in heterosexist terms - hiding his 'feminine' desire for men while attempting to sustain his 'masculine' exterior, albeit usually to comical effect (Clover 1992). In any sense, the spectatorial positions proffered by Clover are destabilised in ANOES2, as the film concerns itself with the gender and sexuality fluidity inherent in Jesse's characterisation. Unlike the final girl, Jesse struggles to navigate the possibilities he faces, especially the courage to overcome both internal and external resistances. Unlike the final girl's astute observations of her surroundings and her ability to define herself against her victimised peers (the heterosexual capability to take control), Jesse's quest registers as introspective - an inward awareness of an inherent monstrosity that necessitates control itself and an on-going reflection and remediation of those inner sexual conflicts.

To conceptualise Jesse as the film's final boy figure, however, is to elide a nuanced account of the film's narrative, whereby Jesse is actually saved by Lisa at the end of the film. Physically colonised by Freddy Krueger, Lisa repeatedly professes her 'love' to Jesse, to which this hegemonic, heterosexual offering literally vanquishes Freddy and rematerialises Jesse. Understood in this way, the final girl figure, the one who 'saves the day' is actually reserved for Lisa, the film's symbolic representation of heteronormativity. As a result, the film presents the postmodern dissolution of fixed roles, for Jesse is simultaneously presented as victim, monster and final boy. As Rhona Berenstein (1996) has so aptly demonstrated through her inference that horror spectatorship, and in turn monster/victim figures are constantly in flux, performative and masqueraded, roles are quite literally fragmented, and a mode of horror spectatorship predicated on male sadomasochism/female

\footnotetext{
${ }^{3}$ See Goffman (1959) for a fruitful insight into the presentation of self in relation to everyday social interactions.
} 
vulnerability is fractured. Although this destabilisation does indeed bring into focus gendered and sexual boundaries, there is a scene foregrounded in the reception that is worth dissecting here, which maintains, to some degree, that Jesse best represents an amalgamation of victim and monster - which resonates strongly with the gay reception of the film.

In this pertinent scene - Jesse's dream about halfway through the film - the ostensibly gay Coach Schneider is murdered in the school shower, next to Jesse, revealing a medium shot of Jesse actually donning the infamous claw of Freddy. Discursively discussing this particular scene, an anonymous user of the popular website Queerhorror.com writes:

Though it is not politically correct I think the story rings true for young men conflicted with their homosexuality. Sure, the coach is a fiend but he represents the seedy and actually a realistic aspect of gay life. There are a few guys out there like him. (Anon. 1999)

An interesting observation is to be noted here between Coach Schneider as a 'realistic' aspect of gay life against which Jesse is disguised by situating himself within the impregnable masquerade of the closet. Jesse donning Freddy's claw offers a moment of personal subjectivity whereby his suppressed homosexuality has temporarily surfaced and acted in aberrant and uncontrollable ways. As a result, the fact that Freddy actually kills the gym coach can be seen to represent Jesse's own inherent fear of conforming to such facets of gay life - of disclosing his (homo)sexuality within a milieu reified through the very notions it seeks to repress. This scene thus culminates in Jesse killing Schneider because of the deep anxiety over what he could become should he act on the homosexual feelings he possesses in his nightmares. Writing on this scene, Harry Benshoff notes, 'this sequence might be read as a metaphoric homosexual panic attack, in which Jesse, having been aroused by the possibility of a sexual encounter with the coach, murders him rather than admit his homosexual feelings' $(1997,248)$. In sum, Jesse is understood as both victim and monster. Even a victim of his own inherent monstrosity which, unless carefully suppressed, will manifest in unpredictable and often fatal ways.

In many ways, Jesse sheds light on Benshoff's conceptualisation of the 'monster queer'. He defines this figure through the following analogy: "the monster is to "normalcy" as homosexual is to heterosexual' $(1997,2)$. The point comes across loudly here: homosexuals are degraded monsters; and, as Benshoff further claims: 'their evil agenda is to destroy the very fabric of American society' $(1997,2)$. However, if in the traditional slasher formula, the monster can be viewed as a disturbed queer 'Other' (Wood 1986) and the final girl is the helpless victim seeking to liberate herself from his evil peril, Jesse represents the amalgamation of the traditional victim and monster figure. It is this conflation, I argue, which invites gay audiences to recognise Jesse's status as something that can speak to them about their own lived realities of being gay, through which notions of being a victim - of being ostracised, bullied and/or provoked - but also recognising their burgeoning monstrous sexuality - may resonate in a series of ways (Michelangelo 1993).

Such identifications with this victim-as-monster concept are particularly noticeable through Dave Fuente's (2011) website 'Terror from Beyond the Daves'. He writes the following:

Many horror fans who grew up homosexual look back on NIGHTMARE ON ELM STREET: FREDDY'S REVENGE with a sombre understanding. Many of us homosexual viewers had also been uncomfortable with Patton's performance, perhaps 
because it hit a little too close to home. Being bullied by a testosterone charged coach and teased by your fellow classmates was, for some of us, a nightmare not exclusive to Elm Street [sic]. (Dave Fuente 2011)

Patton's performance is received here as being perhaps too homologous to the actual homosexual experiences of some audiences, meaning that such retrospective viewings were met with dejected sentiments. Jesse, seen as both victim and monster has the capacity to resonate with gay audiences, for the amalgamation of the two is able to aptly capture their own experiences of an inherent monstrous (read unnatural) sexuality, but also their abject role as victim within a heterosexist society.

\section{Moving Through Nightmares: Navigating Homosexuality through Reception Strategies}

Throughout the film, Jesse's parents Ken (Clu Gulager) and Cheryl (Hope Lange) identify behavioural transformations in their son but cannot delineate them, culminating in a series of questions concerning Jesse's mental state which Jesse perpetually deflects. Of course, Jesse's transparency and subsequent changes in behaviour could also be identified by gay viewers whose own sexual identities may have been speculated by close social circles, usually because of a deviation from a hegemonic masculine ideal epitomised in the film through school-jock character Ron Grady. While on the surface, such a reception of the film may lay claims for the text being homophobic, or at least critical of homosexuality, there is a sense here in which the film's veracious portrayal of Jesse's identity allowed some gay audiences to vicariously identify with Jesse's situation, as that which speaks about their own personal narratives. In this sense, the act of reading the film at a connotative level permits audiences to interpret the film in ways that speaks to the veracity of homosexual experiences registered by the film's online interpretive community.

However, to suggest that the film has transcended homophobic readings would be to miss the point here. For, in a number of gay online spaces, audiences have taken up the issue and problematised the film for its 'homophobic' offerings. In a blog titled 'Queering the Closet', under the heading 'Queer Review: A Nightmare on Elm Street 2: Freddy's Revenge (1985)', author Jeremy Redlien writes the following: 'Not only is Freddy attempting to recruit a teenager to the gay lifestyle, but his newly established queer nature puts an entirely different spin on the fact that he was an established child murderer in the first film'. He adds: 'Freddy Kruger has been sub-textually reinvented as a gay paedophile, thereby creating a film with more homophobic overtones than Cruising ([William Friedkin,] 1980)' (2012). While the argument here may present the film as indeed homophobic, or at least politically regressive, this very notion is predicated on the notion that Jesse is homosexual which is not confirmed - and that the film itself $i$ a conscious narrative of homosexual exploitation - which is unsubstantiated. ${ }^{4}$

The reference to Cruising, furthermore, forges an intertextual comparison whereby a narrative, which features actual gay victims, is said to qualify A Nightmare on Elm Street's own homophobic attitudes based on the idea that gay men are lured into a series of perilous and indeed exposed

\footnotetext{
${ }^{4}$ In some reception accounts, audiences have questioned the extent to which the production team was aware of the gay subtext that some audiences have picked up on. Some even argue that Mark Patton was deliberately coded as gay because of his own homosexuality, while others dismiss such claims.
} 
situations. Unlike the gay and feminist communities in the 1980s who denounced the blatantly homophobic Cruising and equally misogynistic Dressed to Kill (Brian De Palma, 1980) en masse, contemporary gay audiences have consciously 'outed' - even legitimised - ANOES2's textual offerings as consequential to identifying homosexuality and/or remembering their own sexual struggles (Kendrick 2009, 74-78). Although the text is perhaps readable as homophobic, such inferences are reached through associations activated by gay audiences themselves - a result of their quest in attempting to 'out' the film.

What needs to be taken into account, then, is a more nuanced picture of how the contextual factors of gay audiences feed into their affective responses to the film. As Paul Burston and Colin Richardson put it, it is time to "challenge cultural readings which overlook the dynamic of sexual preference [...] [and] explore how lesbians and gay men might position themselves as spectators of popular culture' (1995, 1-2). It is interesting that in the aforementioned reception accounts from Dave Fuente (2011) and Jeffreygmm (2009), the film brought into focus specific moments from their own gay histories, as Jesse's character is said to parallel their own experiences. Indeed, while the former candidly acknowledged the 'sombre' feelings that the film brought into focus, this says more about the film as an authentic representation of their own personal subjectivities, rather than an unequivocal dismissal of the film as homophobic. For although the conflation of homosexuality with monstrosity and victimhood paints a negative picture, it is these correlations which allow for gay audiences to intelligibly 'out' the film as a cultural artefact which speaks about specific gay experiences relating to repressed sexuality and its sequestered effects.

This is comparable to what Susan Driver has noted in relation to her work around queer girls and popular culture: 'Queer girls engage critically and creatively with popular culture as an ongoing articulation of fantasies, feelings and ideas that expands the parameters of what is intelligible' $(2007,21)$. While it could be argued that the film's representational strategies attempt to taint monsters and victims as degenerate homosexual characters, gay audiences have employed interpretive agency to achieve polyvalent and productive readings as a means to overcome these obstacles. Like Jesse, they strive to survive the nightmares subdued deep within the darkness of the horror genre - to make meaning out of what may otherwise be overlooked or ignored and to foreground specific narrative moments that reflect their own lived experiences.

Driver's inference of an 'ongoing articulation' also highlights the ways in which readings are renegotiated and reworked through the mobile nature of a gay subjectivity that constantly reshapes and re-evaluates itself at various moments. For instance, in a forum featured on the popular social network Tribe.net labelled 'Growing Up Gay, With Horror', user 'Robert' 5 proceeds to discuss the gay content of $A N O E S 2$ :

An example popping into my mind is A nightmare on Elm Street 2 and when I saw that it was like [more] well, let's see, I think that had some gay overtones but hmmm not sure maybe I am starting to see gay stuff where is not just cause I found out I am gay ... then when I grew up I was like oh hell yeah that was definitely gay [sic]. (Robert 2005)

\footnotetext{
${ }^{5}$ To ensure that material acquired from online sources are analysed and presented ethically, usernames have been altered from the forum 'Growing Up Gay, With Horror' to ensure the confidentiality of all users. The material within the forum is, however, publically accessible without the need to register in order to access specific privileges.
} 
Responding to Robert, user 'James' legitimises these readings of the film writing: 'Oh, well, yes...Nightmare on Elm Street 2 was definitely homo-erotic...probably the most, out of the series!' (James 2005) Robert's interpretive repertoire is presented as having become intellectually cultivated through the process of growing up, granting him the autonomy to retrospectively authenticate his own youthful readings. Moreover, such an online community also allows other members to validate these readings through their own subjectivities, shifting the focus from personal readings to a wider collective consciousness. This parallels the wider endeavours (or pressures) of the gay individual: to exit the closet as a means of sharing experiences and ultimately, legitimising a series of feelings and experiences which, for many years, may remain confined to oneself.

Discussing this notion of a collective identity, J. Patrick Williams (2011) stresses the importance of sharing a collective gay identity to allow homosexuals to attach positive meaning to what might otherwise be seen as merely individual acts or as a 'pejorative label'. Therefore, coming out represents a shift from a state of individual choice to one of collective identification and action (Williams 2011). Within gay understandings of the horror film itself, then, is a sense in which solitary, tentative readings of these texts are translated into a wider public consciousness where they are mediated and authenticated as legitimate in relation to the experiences of others. The use of the Internet for these audiences, then, allows for utilisation of communal spaces in which various readings are able to coalesce to collectively reveal what they believe to be a narrative about the afflictions of a sexually repressed high school student.

A blog featured on Queerty.com displays a post entitled, 'Who Knew Nightmare on Elm Street 2: Was the Gayest Film of the 80s?' The blog, in turn, was inundated with nineteen comments with various users interrogating not only the film's ostensibly homosexual narrative, but also how the film departs from traditional conventions of the slasher film. Author of the blog, 'JD', writes: 'But who knew making actor Mark Patton - who is gay — the first male scream queen, who Freddy lusted after, would fly over everybody's heads? Including his co-stars?' (2010). There is a sense here in which gay readings of the film are seen as culturally privileged ones - that even Patton's 'co-stars' were unaware of how the film was departing from conventions of the slasher film. The film's inclusion of a male 'scream queen' then, may not signify much at the level of production, but affords a sense of cultural empowerment for those audiences who are able to flex their interpretive muscles and ascribe provocative readings to an otherwise banal slasher film. To borrow from Lawrence Grossberg (1992), these audiences are making their own 'cultural environment' from the resources available to them, taking what is meaningful as a means to legitimise their own fan practices and readings. In many ways then, this active online fandom assists in reconsidering traditional perceptions of the slasher audience as 'sick and stupid' by instead ascribing such pejorative labels to those involved in the production of the film (Hutchings 2004, 83) ${ }^{6}$.

Agency and control over Mark Patton's star image has therefore shifted from the realm of production to one of reception (DeAngelis 2001). Responding to a question from a fan on the Facebook page aforementioned, Patton writes, 'I have nor did I have a desire to pass for straight in

\footnotetext{
${ }^{6}$ In many respects such discursive activity around ANOES2 parallels the gay audiences of The Silence of the Lambs (Dir. Jonathan Demme 1991) and the ways in which they 'outed' Jodie Foster because of her plausibility to bolster the visibility the gay community in the 1990s (Staiger 2000). This kind of 'outing' evidenced in the reception of ANOES2, then, allows the autonomy for gay audiences to appropriate the text as a representation of their own gay histories.
} 
real life [...] only on the screen' (2012). The fact that Jesse's sexuality has been the subject of much communicative exchange, however, supports Michael DeAngelis' claim that, 'across time, a star's potential to be read as gay or 'gay receptive' remains a function of gay culture's historical preferences for representing itself and for responding to these representations' $(2001,8)$. With social histories and cultural narratives of homosexuality appearing with greater frequency, gay audiences have used Mark Patton to reflect upon the homosexual zeitgeist of the 1980s, whilst appropriating him as figure who is able to represent their own struggles and interests. A form of 'insider knowledge' is thus afforded to them within such social media spaces - where textual readings are discussed, mediated and ultimately legitimised by Patton himself.

One scene that is germane to the gay reception of the film can be identified towards the end. While at a pool party hosted by Lisa, Jesse opens up to her about his dreams and about his mental capacity to cope with such. Subsequently, and as a result of this confiding, Lisa and Jesse share an intimate scene of kissing, which has been anticipated throughout. While lying on the floor kissing Lisa, Jesse's tongue elongates and resembles that of a monster - as if to suggest that his homosexual interior (Freddy) is surfacing as a result of this heterosexual encounter. Quite literally here, Jesse's heterosexual quest is disrupted as a result of the monster within, allowing him to look into the mirror at a distorted image of himself. It can be read as though the heterosexual-homosexual pairing is literally an unnatural one, allowing Lisa to view Jesse not as heterosexual male, but as homosexual monster.

Having abandoned Lisa following this encounter, Jesse shows up at a half-naked Grady's house, demanding that he sleep there the night while Grady observes him. He demands Grady to wake him, should he appear disturbed during his sleep. Of course, Jesse experiences another nightmare, but this time, Freddy Krueger manifests himself through Jesse's stomach and proceeds to kill Grady in his bedroom. Having constructed Jesse's heterosexual quest as futile, the film proceeds to explore the potential pairing of Jesse and Grady, only to disrupt such with the surfacing of Freddy, through Jesse. If Freddy represents Jesse's latent homosexuality then, Grady's death signifies the inability for Jesse's sexuality to surface in socially moralistic forms, delimiting homosexuality to the formidable realm of nightmares where it is to be contained and played out in socially nonthreatening ways.

The last few years has witnessed a resurgence of activity around the Nightmare on Elm Street franchise, particularly through remake of the first film (Samuel Bayer, 2010), documentaries (Never Sleep Again: The Elm Street Legacy (Daniel Farrands and Andrew Kasch, 2010; I Am Nancy (Arlene Marechal, 2010)), re-screenings of the film at gay and lesbian film festivals (like Frameline 37 in San Francisco) and a number of interviews carried out with members of cast and crew, particularly Heather Langenkamp and Mark Patton. Central to these activities, the links between homosexuality and the Nightmare on Elm Street franchise have been foregrounded through discussions around fans and the cultural impact of their readings and broader discursive activities. Central to these activities, fans have caught the attention of various members of the production team who have praised, even legitimised the interpretive practices of gay audiences by supporting the viability of their textual readings. However, not only has the gay reception around ANOES2 had significant cultural impact on the franchise and horror genre more broadly, but also the public profile of Mark Patton, who has since disclosed his status as HIV positive and his experiences of working as a gay actor in Hollywood during the 1980s (Peeples 2013). 


\section{Conclusion}

This article has argued that there is an active gay reception around $A$ Nightmare on Elm Street 2: Freddy's Revenge, specifically within interpretive communities who inhabit multiple online contexts. As I have demonstrated, such a reception is best understood at the intersection between textual (and generic) features and the affective responses of gay audiences. Moreover, while elements of the gay online reception of the film could be understood as homophobic or politically regressive, there is a sense in which gay audiences have discursively appropriated and re-coded specific moments in the film that reproduce a sense of their own personal lived realities located through the character of Jesse and his relationship to the monstrous Freddy Krueger. In turn, this has enabled such audiences to legitimise the veracity of their own subjective realities, as they pertain to the historical circumstances of the 1980 s, as well as with the affective states of other gay audiences.

This article has also argued that although the victim and killer/monster figure are still at play in ANOES2, they come to be infused in the figure of the final boy as borders collapse and gender and sexuality become sites of negotiation. For gay audiences, the figure of the final boy reflects more accurately the lived experiences of being both victim and monster figures within a heterosexist society. Jesse's duality was considered in relation to the monstrous figure of Freddy Krueger and also the film's symbolic representation of the final girl, Lisa, who ultimately saves Jesse from Freddy's bodily invasion. Ultimately, this infusion sought to destabilise Clover's theories around (male) spectatorship, to account for the ways in which gay and other non-normative audiences are implicated in those slasher films that do not place a final girl at the centerpiece of their narratives.

Although in his book Making things Perfectly Queer Alexander Doty stresses the importance of 'removing mass culture queerness from the shadowy realm of connotation', this article has hopefully highlighted the value in looking at the ways in which gay audiences have attempted to 'out' ostensibly 'normative' texts (1993, xi). Paradoxically, however, it is within this shadowy realm of connotation that such homosexual states of repression and closeted sexuality are best located, as they are able to speak in subtle yet productive ways about a series of affective states that would otherwise be overlooked in mainstream horror cinema. A Nightmare on Elm Street 2: Freddy's Revenge, may not represent homosexuality explicitly and indubitably, but it does speak to gay audiences about their experiences of coming to terms with their sexuality, which can be measured against the readings of other audiences.

One important question that I have touched on, but for a proper consideration of which there is not space enough here, is how generational differences factor into the gay reception of the film. While I have presented evidence to suggest that ANOES2 is centralised predominately through those (gay) audiences who grew up in the period (and thus utilise the film as a nostalgic apparatus), further research must open the cultural terrain to account for different generational experiences which operate within the complex spaces of gay media reception. Further, work is also required to extend this concern to other audience demographics, looking at how the text is understood in lesbian or heterosexual spaces, and whether similar readings are generated around Jesse and his gay nightmares on Elm Street. 


\section{References}

Benshoff, H. (1997) Monsters in the Closet: Homosexuality and the Horror Film, Manchester: Manchester University Press

Berenstein, R. J. (1996) Attack of the Leading Ladies: Gender, Sexuality, and Spectatorship in Classic Horror Cinema, New York: Columbia University Press

Burston, P. and Richardson, C. (1995) A Queer Romance: Lesbians, Gay Men, and Popular Culture, London: Routledge

Carroll, N. (1990) The Philosophy of Horror, Or, Paradoxes of the Heart, New York: Routledge

Clover, C. J. (1992) Men Women and Chainsaws: Gender in the Modern Horror Film, New Jersey: Princeton University Press

Cook, P. (2005) Screening the Past: Memory and Nostalgia in Cinema, London: Routledge.

Creed, B. (1993) The Monstrous-feminine: Film, Feminism, Psychoanalysis, London: Routledge

DeAngelis, M. (2001) Gay Fandom and Crossover Stardom: James Dean, Mel Gibson, and Keanu Reeves, Durham: Duke University Press

Doty, A. (1993) Making Things Perfectly Queer: Interpreting Mass Culture, Minneapolis: University of Minnesota

Driver, S. (2007) Queer Girls and Popular Culture: Reading, Resisting, and Creating Media, New York: Peter Lang.

Duda, H. (2008) The Monster Hunter in Modern Popular Culture, Jefferson, North Carolina: McFarland \& Company, Inc

Goffman, E. (1959) The Presentation of Self in Everyday Life, Garden City, New York: Doubleday

Grant, B. K. (ed.) (1996) The Dread of Difference: Gender and the Horror Film. Austin: University of Texas

Grossberg, L. (1992) 'Is There a Fan in the House?: The Affective Sensibility of Fandom', in L. A. Lewis (ed.), The Adoring Audience: Fan Culture and Popular Media, London: Routledge, pp. 50-68

Halberstam, J. (2005) In a Queer Time and Place: Transgender Bodies, Subcultural Lives, New York: New York University Press

Hutchings, P. (2004) The Horror Film, Harlow: Pearson Longman

Kendrick, J. (2009) Hollywood Bloodshed: Violence in 1980s American Cinema, Carbondale: Southern Illinois University Press

Oliver, M. B. and Sanders, M. (2004) 'The Appeal of Horror and Suspense', in S. Prince (ed.), The Horror Film, New Brunswick, NJ: Rutgers University Press, pp. 242-59

Rieser, K. (2001) 'Masculinity and Monstrosity: Characterization and Identification in the Slasher Film', Men and Masculinities, 3(4), 370-92

Saunders, M. W. (1998) Imps of the Perverse: Gay Monsters in Film, Westport: Praeger 
Staiger, J. (2000) Perverse Spectators: The Practices of Film Reception, New York: New York University Press

Twitchell, J. B. (1985) Dreadful Pleasures: An Anatomy of Modern Horror, New York: Oxford University Press

Williams, J. P. (2011) Subcultural Theory: Traditions and Concepts, Cambridge, UK: Polity Wood, R. (1986) Hollywood from Vietnam to Reagan, New York: Columbia University Press

\section{Web Sources}

Anonymous (1999) 'Nightmare on Elm Street - Part 2: Freddy's Revenge, A', QueerHorror.com, [review forum]. Accessible at http://www.queerhorror.com/items/224.html. Accessed 11 September 2013

'Buzz' (2009) 'A Nightmare on Elm Street 2: Freddy's Revenge - The Gaypex of Horror Cinema' Campblood.org, [blog], 21 August. Accessible at http://campblood.org/Newblog/archives/265. Accessed 10 September 2013

Fuente, D. (2011) 'Coming Out of Horror's Closet: Mark Patton From Nightmare on Elm Street 2: Freddy's Revenge', TerrorDaves.com, [blog], n.d. Accessible at http://terrordaves.com/2011/06/27/coming-out-of-horrors-closet-mark-patton-fromnightmare-on-elm-street-2-freddys-revenge/. Accessed 14 September 2013

'James' (2005) 'Growing Up Gay, With Horror', Tribe.net, [forum]. Accessible at http://gaysintohorror.tribe.net/thread/c6bccdb8-624b-43f6-ad8e-3a51857bfd56. Accessed 20 September 2013

'JD' (2010) 'Who Knew Nightmare on Elm Street 2 Was the Gayest Film of the 80s?', Queerty.com, [blog], 21 June. Accessible at http://www.queerty.com/who-knew-nightmareon-elm-street-2-was-the-gayest-film-of-the-80s-20100621/. Accessed 9 September 2013

'Jeffreyggm' (2009) ‘Did You Ever See a Dream Walking?', Now Kindly Undo These Straps, [blog], 30 September. Accessible at http://www.faggotyasshorror.com/2009/09/didyou-ever-see-dream-walking.html. Accessed 14 September 2013

Liaguno, V. (2008) 'The Queer Appeal of Slasher Films', Slasher Speak, [blog], 2 January. Accessible at http://vinceliaguno.blogspot.co.uk/2008/02/why-slasher-films.html. Accessed 15 September 2013

Patton, M. (2012) 'Mark Patton, The Real Me' [Facebook group]. Accessible at https://www.facebook.com/groups/305410446202347/?fref=ts. Accessed 20 September 2013

Peeples, J. (2013) 'A Nightmare in Hollywood Couldn't Kill Mark Patton', Advocate.com, 8 August. Accessible at http://www.advocate.com/health/hiv-aids/2013/08/08/scream-kingnightmare-hollywood-couldnt-kill-mark-patton?page=0,3. Accessed 7 September 2013

Redlien, J. (2012) 'Queer Review: A Nightmare on Elm Street 2: Freddy's Revenge (1985)', Queering the Closet, [blog], 30 October. Accessible at http://queeringthecloset.blogspot.co.uk/2012/10/queer-review-nightmare-on-elm-street2.html. Accessed 22 September 2013 
'Robert' (2005) 'Growing Up Gay, With Horror', Tribe.net, [forum]. Accessible at http://gaysintohorror.tribe.net/thread/c6bccdb8-624b-43f6-ad8e-3a51857bfd56. Accessed 20 September 2013

\section{Filmography}

A Nightmare on Elm Street (1984), directed by Wes Craven, USA: New Line Cinema A Nightmare on Elm Street 2: Freddy's Revenge (1985), directed by Jack Sholder, USA: New Line Cinema

Cruising (1980), directed by William Friedkin, USA: United Artists Dressed to Kill (1980), directed by Brian De Palma, USA: Filmways Pictures I Am Nancy (2011), directed by Arlene Marechal, USA: Camelot Entertainment Group. Never Sleep Again: The Elm Street Legacy (2010), directed by Daniel Farrands and Andrew Kasch, USA: 1428 Films.

The Burning (1981), directed by Tony Maylam, USA: Filmways 